\title{
Trust, Personal Moral Codes, and the Resource-Advantage Theory of Competition: Explaining Productivity, Economic Growth, and Wealth Creation
}

Shelby D. Hunt ${ }^{1}$

ABSTRACT

KEY WORDS: trust, competition, productivity, economic growth, resource-advantage theory, Hunt-Vitell theory

\begin{abstract}
Scholars agree that societal-level moral codes that promote social trust also promote wealth creation. However, what specific kinds of societal-level moral codes promote social trust? Also, by what specific kind of competitive process does social trust promote wealth creation? Because societal-level moral codes are composed of or formed from peoples' personal moral codes, this article explores a theory of ethics, known as the "Hunt-Vitell" theory of ethics, that illuminates the concept of personal moral codes and uses the theory to discuss which types of personal moral codes foster trust and distrust in society. This article then uses resource-advantage (R-A) theory, one of the most completely articulated dynamic theories of competition, to show the process by which trust-promoting, societal-level moral codes promote productivity and economic growth. That is, they promote wealth creation.
\end{abstract}

JEL Classification: D40, O40

\section{Introduction}

How does trust within a society relate to that society's productivity and economic growth, that is, its wealth creation? Scholars across a wide range of disciplines maintain that societal-level moral codes that promote social trust promote wealth creation (e.g., Fukuyama, 1995; Gambetta, 1988; Harrison, 1992; Phelps, 1975). In economics, for example, Arrow (1972) hypothesized over three decades ago that because "[v]irtually every commercial transaction has within itself an element of trust, ... [it] can be plausibly argued that much of the economic

\section{-}

Corespondence concerning to this article should be addressed to: shelby.hunt@ttu.edu backwardness in the world can be explained by the lack of mutual confidence". (p. 357). He refers to trust as one of society's "invisible institutions." As such, trust stems from "principles of ethics and morality" and promotes economic growth because it is an "important lubricant of the social system" (Arrow, 1974, pp. 23, 26).

As a second example, Harrison (1992, p.1), an economic development advisor, asks: "Why do some nations and ethnic groups do better than others?" And he answers: "The overriding significance of culture is the paramount lesson I have learned in my thirty years of work on political, economic, and social development." What, then, are the characteristics of a culture that will engender prosperity, one that is progress-prone? This is Harrison's (1992) answer: 

(2006), which is displayed in Figure 1. The model addresses the situation in which an individual confronts a problem perceived as having ethical content. This perception of an ethical problem in the situation triggers the process depicted by the model. If the individual does not perceive some ethical content in a problem situation, subsequent elements of the model do not come into play. Given that an individual perceives a situation as having ethical content, the next step is the perception of various possible alternatives or actions that might be taken to resolve the ethical problem. It is unlikely that an individual will recognize the complete set of possible alternatives. Therefore, the evoked set of alternatives will be less than the universe of potential alternatives. Indeed, ultimate differences in behaviors among individuals in situations that have ethical content may be traced, in part, to differences in their sets of perceived alternatives.

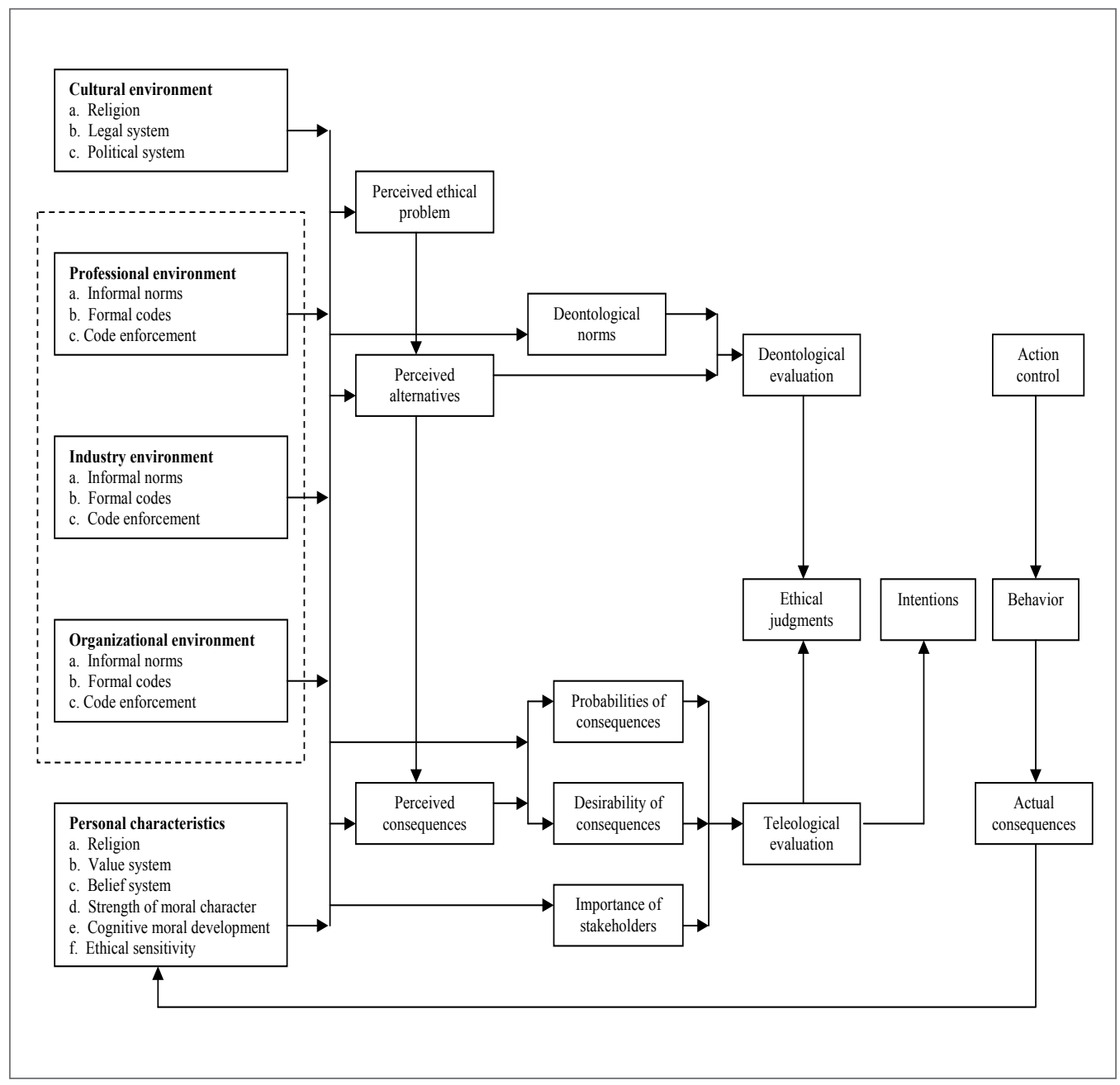

Figure 1. Hunt-Vitell Theory of Ethics. The portion of the model outside the dashed lines constitutes the general theory. The portion inside the dashed lines individuates the general model for professional and managerial contexts. Source: Hunt and Vitell $(1986,1993)$. Copyright $\odot 1991$ by Shelby D. Hunt and Scott J. Vitell 

maintains that it is unlikely that such a result would be found across many individuals and different situations. Similarly, though it is possible that some people in some situations might be strict (e.g., "utilitarian") teleologists (i.e., $\mathrm{DE}=$ zero), such a result is unlikely across many individuals and situations.

Consistent with general theories in consumer behavior (e.g., Engel, Blackwell, \& Kollat, 1978; Howard \& Sheth,1969) and the Fishbein and Ajzen (1975) model, the $\mathrm{H}-\mathrm{V}$ model posits that ethical judgments impact behavior through the intervening variable of intentions. Like Petty and Cacioppo (1986) and Jones (1991), the H-V model proposes that both ethical judgments and intentions should be better predictors of behavior in situations where the ethical issues are central, rather than peripheral.

The $\mathrm{H}-\mathrm{V}$ model proposes that ethical judgments will sometimes differ from intentions because TE also independently affects intentions. That is, though an individual may perceive a particular alternative as the most ethical, the person may intend to choose another alternative because of certain preferred consequences (e.g., there might be significant positive consequences to one's self as a result of choosing the less ethical alternative). The theory suggests that when behavior and intentions are inconsistent with ethical judgments, there will be feelings of guilt. Therefore, two individuals, $A$ and $B$, may engage in the same behavior, yet only $A$ may feel guilty, because B's behavior is consistent with his or her ethical beliefs.

What is called action control in the model is the extent to which an individual actually exerts control in the enactment of an intention in a particular situation (Ajzen, 1985; Tubbs \& Ekeberg, 1991). That is, situational constraints may result in behaviors that are inconsistent with intentions and ethical judgments. One such situational constraint may be the opportunity to adopt a particular alternative. Zey-Ferrell, Weaver, and Ferrell (1979) empirically document the influence of opportunity on behavior in situations having ethical content. Similarly, Mayer (1970) identifies opportunity as being a condition that impinges on ethical behavior.

After behavior, there will be an evaluation of the actual consequences of the alternative selected. This is the major learning construct in the model. These actual consequences provide feedback to the category of variables labeled "Personal Characteristics." He- garty and Sims (1978) examined whether a system of perceived rewards and punishments could change behaviors in a situation involving ethical content. They concluded that "the results lend support to the notion that many individuals can be conditioned (i.e., can "learn") to behave unethically under appropriate contingencies" (p. 456). Conversely, of course, the H-V theory maintains that individuals can be conditioned to behave ethically.

The $\mathrm{H}-\mathrm{V}$ model identifies several personal characteristics that might influence specific aspects of the ethical, decision-making process. Unquestionably, an individual's personal religion influences ethical decision making. A priori, compared with nonreligious people, one might suspect that (1) highly religious people would have more clearly defined deontological norms and (2) such norms would play a stronger role in ethical judgments. Vitell, Paolillo, and Singh (2005), in a consumer ethics setting, examined the impact of both intrinsic and extrinsic religiosity on ethical beliefs, where the former is characterized by individuals sincerely incorporating faith and religious beliefs into everyday life, and the latter is characterized by individuals simply using religion as a source of comfort, social support, self-justification, and/or status. Their findings indicate that while extrinsic religiosity has little impact on one's ethical beliefs, intrinsic religiosity is a significant determinant of consumer ethical beliefs.

An individual's value system would also impact the decision process. In general, we urge researchers to explore many different values and the extent to which these values impact ethical decision making. Consider, for example, "organizational commitment" as one such value. Hunt, Wood, and Chonko (1989) found corporations that have high ethical values will, subsequently, have employees more committed to the organization's welfare. This is an apparently positive outcome. However, is it possible that individuals exhibiting high organizational commitment (even because of the organization's ethical values) will then place such great importance on the welfare of the organization that they may engage in questionable behavior if such behavior were thought to be beneficial to the organization? A four-country study (Vitell \& Paolillo, 2004) indicates a link between organizational commitment and the decision maker's perception that ethics should be a long-term, top priority of the organization. 

According to the $\mathrm{H}-\mathrm{V}$ model, differences in personal moral codes result from differences in:

- the rules for combining the deontological and teleological evaluations;

- the deontological norms held;

- the relative importance of particular norms;

- the rules for resolving conflicts among norms;

- the rules for interpreting the applicability of norms in particular situations;

- the importance weights assigned to particular stakeholders;

- the rules for combining the teleological components;

- the perceived positive consequences for particular (e.g., highly important) stakeholders;

- the perceived negative consequences for particular (e.g., very unimportant) stakeholders;

- the perceived probabilities of positive and negative consequences for particular stakeholders.

Some people's personal moral codes emphasize deontological factors; others emphasize teleological factors. Some codes are trust-inducing; others produce distrust.

Consider the personal moral code implied by the neoclassical tradition in economics. Neoclassical economics assumes that everyone is a utility maximizer, which is interpreted as self-interest maximization. In terms of the $\mathrm{H}-\mathrm{V}$ model, Deontological Evaluation is zero, and all ethical judgements are formed solely by Teleological Evaluation. Furthermore, the importance weights assigned to all stakeholders other than one's self are assigned zero. Therefore, in the neoclassical tradition in economics, all persons have personal moral codes that lead them to choose the alternative that has the highest score in a highly circumscribed Teleological Evaluation process in which the importance weights for all stakeholders other than one's self are zero.

For example, Williamson's (1975, p. 255) transaction cost economics assumes that "economic man...is thus a more subtle and devious creature than the usual selfinterest seeking assumption reveals." For transaction cost economics, homo economics not only self-interest maximizes but does so with opportunistic "guile." Williamson argues for assuming universal opportunism because it is "ubiquitous" (1981, p. 1550), "even among the less opportunistic types, most have their price" (1979, p. 234), and opportunistic "types cannot be distinguished ex ante from sincere types" (1975, p. 27) or, at the very least, "it is very costly to distinguish opportunistic from nonopportunis- tic types ex ante" (1981, p. 1545). Even though, as Williamson acknowledges, "to craft credible commitments... is to create functional substitutes for trust," (1994, p. 7) he maintains that "the study of economic organization is better served by treating economic organization without reference to trust" (1993, p. 99).

The preceding shows how some personal moral codes spawn distrust. Specifically, if a society's dominant culture actually focuses solely on Teleological Evaluation, with importance weights of zero for all stakeholders other than one's self, then social trust cannot exist: the universal opportunism of such a restricted moral code implies that one must always presume nontrustworthy behavior by others. As a consequence, Etzioni (1988) points out: "The more people accept the [utility maximization part of the] neoclassical paradigm as a guide for their behavior, the more their ability to sustain a market economy is undermined."( p. 257)

Etzioni (1988) cites empirical studies suggesting that neoclassical theory, as interpreted by students, licenses opportunism. For students, "is" becomes "ought." For example, the studies of Marwell and Ames (1981) find a positive correlation between formal training in economics and the frequency of free riding. If everyone free rides, students apparently conclude that they might as well free ride also. As a second example, Frank, Gilovich, and Regan (1993) distributed questionnaires to students concerning their likelihood of engaging in dishonest behavior at the beginning and end of three classes: (1) an economics class in which both the book and the instructor stressed neoclassical theory, (2) an economics class in which the book stressed neoclassical theory but the instructor did not, and (3) an astronomy class as a control. Students in all three classes were more dishonest at the end of the semester than at the beginning. However, the shift toward dishonesty by students in the two economics classes was greater than that of those in the control group. Furthermore, the shift toward dishonesty was greater in the economics class where the professor emphasized and supported neoclassical theory than in the class where only the textbook did so. Students, as Etzioni (1988) points out, are indeed "learning" the lesson of neoclassical theory: opportunism is universal, why fight it?

If personal moral codes that presume utility maximization spawn distrust, which moral codes present trust? Etzioni (1988) argues for personal moral 



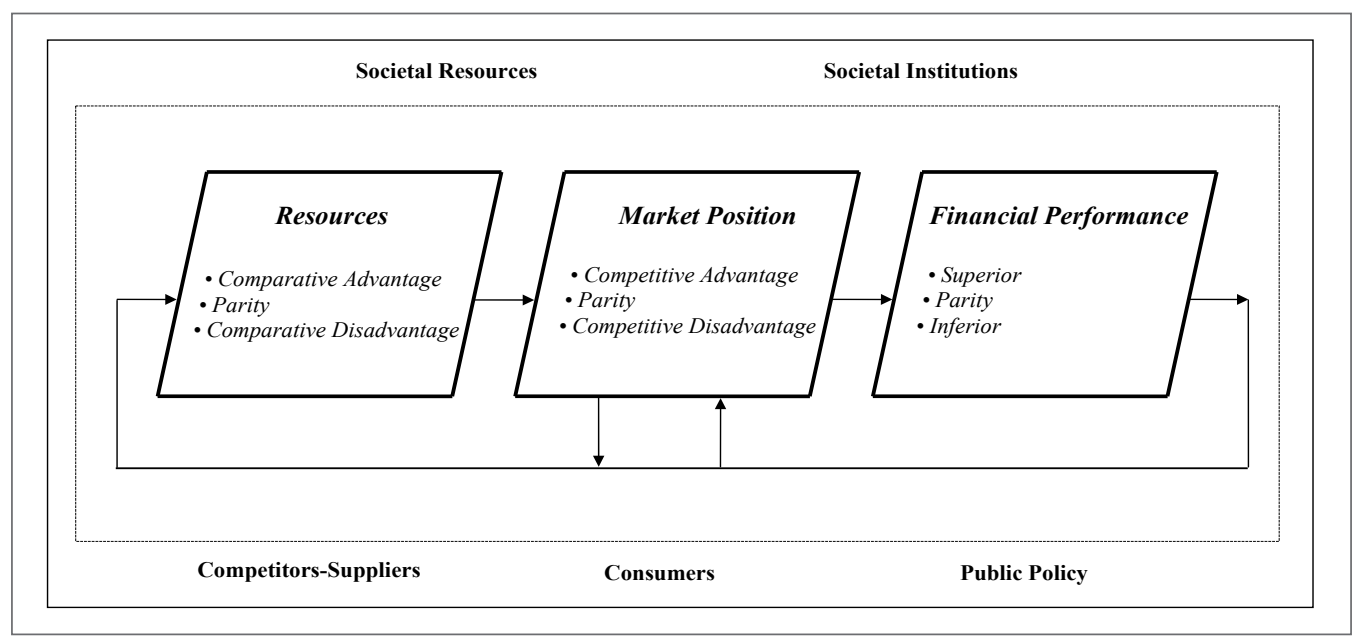

Figure 2. A Schematic of the Resource-Advantage Theory of Competition. Adapted from Hunt and Morgan (1997). READ: Competition is the disequilibrating, ongoing process that consists of the constant struggle among firms for a comparative advantage in resources that will yield a marketplace position of competitive advantage and, thereby, superior financial performance. Firms learn through competition as a result of feedback from relative financial performance "signaling" relative market position, which, in turn signals relative resources.

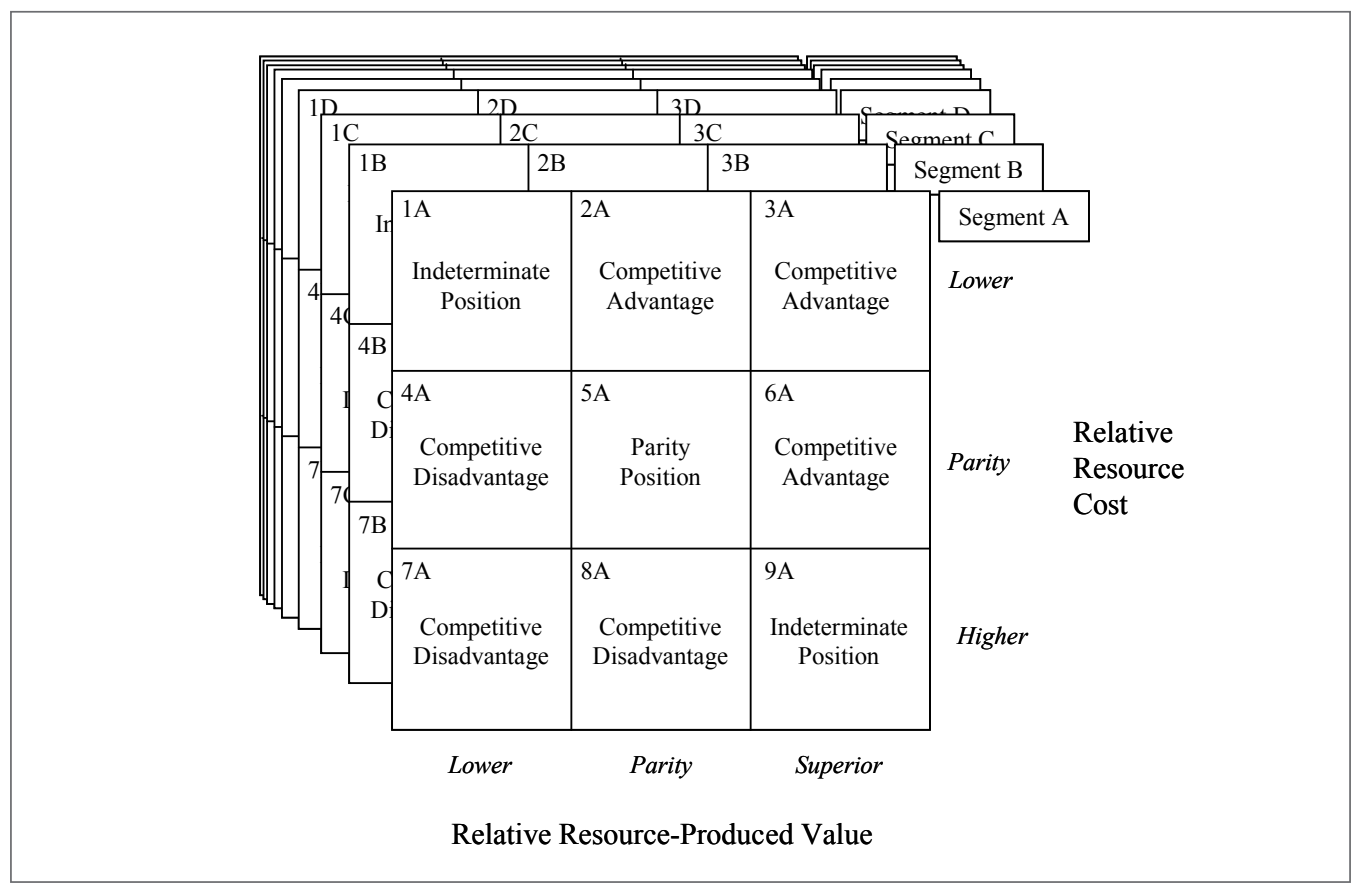

Figure 3. Competitive Position Matrix. Adapted from Hunt and Morgan (1997).

Read: The marketplace position of competitive advantage identified as Cell 3A, for example, in segment A results from the firm, relative to its competitors, having a resource assortment that enables it to produce an offering that (a) is perceived to be of superior value by consumers in that segment and $(b)$ is produced at lower costs than rivals.

Note: Each competitive position matrix constitutes a different market segment (denoted as segment $\mathrm{A}$, segment $\mathrm{B}, \ldots$ ). 

competitors and suppliers, the behaviors of consumers, and public policy decisions.

Consistent with its Schumpeterian heritage, R-A theory places great emphasis on innovation, both proactive and reactive. The former is innovation by firms that, although motivated by the expectation of superior financial performance, is not prompted by specific competitive pressures-it is genuinely entrepreneurial in the classic sense of entrepreneur. In contrast, the latter is innovation that is directly prompted by the learning process of firms' competing for the patronage of market segments. Both proactive and reactive innovation can be "radical" or "incremental," and both contribute to the dynamism of R-A competition.

Firms (attempt to) learn in many ways-by formal market research, seeking out competitive intelligence, dissecting competitor's products, benchmarking, and test marketing. What R-A theory adds to extant work is how the process of competition itself contributes to organizational learning. As the feedback loops in Figure 2 show, firms learn through competition as a result of the feedback from relative financial performance signaling relative market position, which in turn signals relative resources. When firms competing for a market segment learn from their inferior financial performance that they occupy positions of competitive disadvantage (see Figure 3), they attempt to neutralize and/or leapfrog the advantaged firm(s) by acquisition and/or innovation. That is, they attempt to acquire the same resource as the advantaged firm(s) and/or they attempt to innovate by imitating the resource, finding an equivalent resource, or finding (creating) a superior resource. Here, "superior" implies that the innovating firm's new resource enables it to surpass the previously advantaged competitor in terms of either relative costs (i.e., an efficiency advantage), or relative value (i.e., an effectiveness advantage), or both.

Firms occupying positions of competitive advantage can continue to do so if (1) they continue to reinvest in the resources that produced the competitive advantage, and (2) rivals' acquisition and innovation efforts fail. Rivals will fail (or take a long time to succeed) when an advantaged firm's resources are either protected by such societal institutions as patents, or the advantage-producing resources are causally ambiguous, socially or technologically complex, tacit, or have time compression diseconomies.
Competition, then, is viewed as an evolutionary, disequilibrium-provoking process. It consists of the constant struggle among firms for comparative advantages in resources that will yield marketplace positions of competitive advantage and, thereby, superior financial performance. Once a firm's comparative advantage in resources enables it to achieve superior performance through a position of competitive advantage in some market segment(s), competitors attempt to neutralize and/or leapfrog the advantaged firm through acquisition, imitation, substitution, or major innovation. R-A theory is, therefore, inherently dynamic. Disequilibrium, not equilibrium, is the norm. In the terminology of Hodgson's (1993) taxonomy of evolutionary economic theories, R-A theory is non-consummatory: it has no end-stage, only a never-ending process of change. The implication is that, though market-based economies are moving, they are not moving toward some final state, such as a Pareto-optimal, general equilibrium.

\section{Status of the R-A theory research program}

Resource-advantage theory has been subjected to numerous investigations. These studies have revealed the theory to be able to explain, predict, and understand a wide range of phenomena. What follows is a sample of the areas previously examined. (To improve readability, we do not provide multiple cites from individual articles. Instead, we provide specific page numbers from Hunt (2000b), which in turn references other articles.)

R-A theory contributes to explaining firm diversity (pp. 152-155), makes the correct prediction concerning financial performance diversity (pp. 153-155), contributes to explaining observed differences in quality, innovativeness, and productivity between marketbased and command-based economies (pp. 169-170), shows why competition in market-based economies is dynamic (pp. 132-133), incorporates a resource-based view of the firm (pp. 85-86), incorporates the competence view of the firm (pp. 87-89), has the requisites of a phylogenetic, non-consummatory, and disequilibrium-provoking theory of competition (pp. 23-24), explicates the view that competition is a process of knowledge discovery (pp. 29-30, 145-147), contributes to explaining why social relations constitute a resource only contingently (pp. 100-102), and has the requisites 

in $A$ because $B$ 's firms will be both more efficient and more effective in producing valued market offerings. Therefore, nation $B$ is better able than $A$ to reap the gains from trade with $C$, resulting in further increases in $B$ 's productivity and growth, relative to $A$.

Recall that a resource is any entity, tangible or intangible, that is available to (not necessarily owned by) the firm that enables it to produce valued market offerings. The preceding analysis implies that, just as employees having a moral code stressing deontological ethics constitutes a firm resource, a society having a dominant culture with a moral code stressing deontological ethics has a societal resource upon which firms can draw. Thus, R-A theory-alone among theories of competition-can explain how such macro-level, informal institutions as moral codes can contribute to (or from) firm-level, superior financial performance. In so doing, it contributes to explaining how societal institutions that promote social trust also promote the wealth of nations.

\section{Conclusion}

Scholars from numerous disciplines maintain that societal-level moral codes that promote social trust promote wealth creation. Despite this consensus, the nature of the kinds of societal-level moral codes that promote social trust remains unclear. Also remaining unclear is the specific competitive process by which social trust promotes productivity and economic growth, that is, wealth creation. Using the Hunt-Vitell theory of ethics, this article explicates the concept of personal moral codes as a means of understanding societal-level moral codes. We show that societal-level codes based on utility maximization promote social distrust. In contrast, societal-level codes based on deontological ethics promote social trust. Furthermore, we show how, using the resource-advantage theory of competition, that societal-level moral codes that produce social trust also promote productivity and economic growth. Thus, we explain how social trust promotes the wealth of nations.

\section{References}

Ajzen, I. (1985). From intentions to actions: A theory of planned behavior. In J. Kuhl \& J. Beckman (Eds.), Action control: From cognition to behavior (11-39). Berlin: Springer-Verlag.
Arnett, D.B. \& S. D. Hunt. (2002). Competitive irrationality: The influence of moral philosophy. Business Ethics Quarterly, 12, 279-303.

Arrow, K. J. (1972). Gifts and exchanges. Philosophy and Public Affairs, 1, 343-61.

Arrow, K. J. (1974). The limits of organizations. Cambridge, MA: Harvard University Press.

Bebeau, M, J., J. R. Rest, \& C. M. Yamoor. (1985). Measuring dental students ethical sensitivity. Journal of Dental Education, 49, 225-35.

Burns, J. O. \& P. Kiecker. (1995). Tax practitioner ethics: An empirical investigation of organizational consequences. The Journal of the American Taxation Association, 17 (2): 20-49.

Donaldson, T. \& T. W. Dunfee. (1994). Towards a unified conception of business ethics: Integrative social contracts theory. Academy of Management Review, 19 (April), 85-112.

Donoho, C.L., M.J. Polonsky, J. Herche, \& M.J. Swenson. (1999). A cross cultural examination of the general theory of marketing ethics: Does it apply to the next generation of marketing managers? In S. Smith (Ed.), Proceedings of the Seventh Cross Cultural Research Conference. Cancun, Mexico.

Dunfee, T. W., N. C. Smith, \& W. T. Ross Jr. (1999). Social contracts and marketing ethics. Journal of Marketing, 63 (July),14-32.

Etzioni, A. (1988). The moral dimension: Toward a new economics. New York, NY: The Free Press.

Fishbein, M. \& I. Ajzen. (1975). Belief, attitude, intention and behaviour: An introduction to theory and research. Reading, MA: Addison-Wesley.

Foss, N. (1993). Theories of the firm: Contractual and competence perspectives. Journal of Evolutionary Economics, 3, 127-144.

Foss, N. (2000). The Dangers and Attractions of Theoretical Eclecticism. Journal of Macromarketing, 20 (June), 65-67.

Frank, R. H., T. Gilovich, \& D. T. Regan. (1993). Does Studying Economics Inhibit Cooperation? Journal of Economic Perspectives, 7, 159-71.

Frankena, W. (1963). Ethics. Englewood Cliffs, NJ: Prentice-Hall, Inc.

Fukuyama, F. (1995). Trust: The Social Virtues and the Creation of Prosperity. New York, NY: Free Press.

Gambetta, D. (1988). Trust: making and breaking cooperative relationships. New York, NY: Basil Blackwell. 
Goolsby, J. R. \& S. D. Hunt. (1992). Cognitive moral development and marketing. Journal of Marketing, 56 (January), 55-68.

Grengs, C. M. (2006). Verizon v. Trinko: From post-Chicago antitrust to resource-advantage competition. Journal of Law, Economics, \& Policy, 2 (1), 105-144.

Harrison, L.E. (1992). Who prospers?: How cultural values shape economic and political success. New York, NY: Basic Books.

Hegarty, W. H. \& H. P. Sims. (1978). Some determinants of unethical behavior: An experiment. Journal of Applied Psychology, 63 (4), 451-57.

Hodgson, G. M. (1993). Economics and evolution. Ann Arbor, MI: University of Michigan Press.

Hodgson, G.M. (2000). The marketing of wisdom: Resource-advantage theory. Journal of Macromarketing, 20 (June), 68-72.

Howard, J. A. \& J. N. Sheth. (1969). The theory of buyer behavior. New York, NY: Wiley.

Hunt, S. D. (1995). The resource-advantage theory of competition: Toward explaining productivity and economic growth. Journal of Management Inquiry, 4 (December), 317-32.

Hunt, S. D. (1997a). Competing through relationships: Grounding relationship marketing in resource advantage theory. Journal of Marketing Management, 13, 431-445.

Hunt, S. D. (1997b). Evolutionary economics, endogenous growth models, and resource-advantage theory. Eastern Economic Journal, 23 (4), 425-39.

Hunt, S. D. (1997c). Resource-advantage theory: An evolutionary theory of competitive firm behavior? The Journal of Economic Issues, 31 (March), 5977.

Hunt, S. D. (1997d). Resource-advantage theory and the wealth of nations. The Journal of Socio-Economics, 26 (4), 335-57.

Hunt, S. D. (1998). Productivity, economic growth, and competition: Resource allocation or resource creation? Business and the Contemporary World, 10, 367-394.

Hunt, S. D. (1999). The strategic imperative and sustainable competitive advantage: Public policy and resource advantage theory. Journal of Academy of Marketing Science, 27 (2), 144-159.

Hunt, S. D. (2000a). The competence-based, resourceadvantage, and neoclassical theories of competi- tion: Toward a synthesis. In R. Sanchez \& A. Heene (Eds.), Competence-Based Strategic Management: Theory and Research (177-208). Greenwich, CT: JAI Press.

Hunt, S. D. (2000b). A general theory of competition: Resources, competences, productivity, economic growth. Thousand Oaks, CA: Sage Publications.

Hunt, S. D. (2000c). A general theory of competition: Too eclectic or not eclectic enough? Too incremental or not incremental enough? Too neoclassical or not neoclassical enough? Journal of Macromarketing, 20 (1), 77-81.

Hunt, S. D. (2000d). Synthesizing resource-based, evolutionary and neoclassical thought: resourceadvantage theory as a general theory of competition. In N. J. Foss \& P. Robertson (Eds.), Resources, Technology, and Strategy (53-79). London, UK: Routledge

Hunt, S. D. (2001). A general theory of competition: Issues, answers, and an invitation. European Journal of Marketing, 35, 524-548.

Hunt, S. D. (2002a). Foundations of marketing theory: Toward a general theory of marketing. Armonk, NY: M.E. Sharpe.

Hunt, S. D. (2002b). Truth and scientific realism. Unpublished working paper, Marketing Department. Lubbock, TX: Texas Tech University.

Hunt, S. D. (2002c). Resource-advantage theory and Austrian economics. In N. J. Foss \& P. Klein (Eds.), Entrepreneurship and the Firm: Austrian Perspectives on Ecomonic Organization. Cheltenham, UK: Elgar.

Hunt, S. D. \& D.B. Arnett. (2001). Competition as an evolutionary process and antitrust policy. Journal of Public Policy and Marketing, 20 (1), 15-25.

Hunt, S. D. \& D.B. Arnett. (2003). Resource-advantage theory and embeddedness: Explaining R-A theory's explanatory success. Journal of Marketing Theory and Practice, 11 (1), 1-16.

Hunt, S. D. \& D.B. Arnett. (2004). Market segmentation strategy, competitive advantage, and public policy: Grounding segmentation strategy in resource-advantage theory. Australasian Marketing Journal, 12 (1), 7-25.

Hunt, S. D. \& D.B. Arnett. (2006). Does marketing success lead to market success? Journal of Business Research, 59, 820-828. 
Hunt, S. D. \& C. Derozier. (2004). The normative imperatives of business and marketing strategy: Grounding strategy in resource-advantage theory. Journal of Business and Industrial Marketing, 19(1), 5-22.

Hunt, S. D. \& D.F. Duhan. (2002). Competition in the third millennium: Efficiency or effectiveness? Journal of Business Research, 55 (2), 97-102.

Hunt, S. D. \& C. J. Lambe. (2000). Marketing's contribution to business strategy: Market orientation, relationship marketing, and resource-advantage theory. International Journal of Management Reviews, 2 (1), 17-44.

Hunt, S. D. \& S. Madhavaram. (2006a). Teaching marketing strategy: Using resource-advantage theory as an integrative theoretical foundation. Journal of Marketing Education, 28 (2), 93-105.

Hunt, S. D. \& S. Madhavaram. (2006b). The servicedominant logic of marketing: Theoretical foundations, pedagogy, and resource-advantage theory. In R.F. Lusch \& S.L. Vargo (Eds.), The ServiceDominant Logic of Marketing: Dialog, Debate, and Directions (85-90). Armonk, NY: M.E. Sharpe.

Hunt, S. D. \& R.M. Morgan. (1995). The comparative advantage theory of competition. Journal of Marketing, 59 (April), 1-15.

Hunt, S. D. \& R.M. Morgan. (1996). The resourceadvantage theory of competition: Dynamics, path dependencies, and evolutionary dimensions. Journal of Marketing, 60 (October), 107-114.

Hunt, S. D. \& R.M. Morgan. (1997). Resource-advantage theory: A snake swallowing its tail or a general theory of competition? Journal of Marketing, 61 (October), 74-82.

Hunt, S. D. \& R.M. Morgan. (2005). The resourceadvantage theory of competition: A review. In N. K. Malhotra, (Ed.), Review of Marketing Research (153-205). Armonk, NY: M.E. Sharpe,.

Hunt, S. D. \& A. Vasquez-Parraga. (1993). Organizational consequences, marketing ethics and salesforce supervision. Journal of Marketing Research, 30 (February), 78-90.

Hunt, S. D. \& S. M. Vitell. (1986). A general theory of marketing ethics. Journal of Macromarketing, 6 (Spring), 5-15.

Hunt, S. D. \& S. J. Vitell (2006), The general theory of marketing ethics: A revision and three questions. Journal of Macromarketing, 26 (2), 143-153.
Hunt, S. D., V. R. Wood, \& L. B. Chonko. (1989). Corporate ethical values and organizational commitment in marketing. Journal of Marketing, 53 (July), 79-90.

Jones, T. M. (1991). Ethical decision making by individuals in organizations: An issue-contingent model. Academy of Management Review, 16 (February), 366-95.

Kohlberg, L. (1984). Essays on moral development: Vol. II The psychology of moral development. New York, NY: Harper and Row.

Langlois, R. N. \& P.L. Robertson. (1995). Firms, markets and economic change: A dynamic theory of business institutions. London, UK: Routledge.

Marwell, G. \& R. E. Ames. (1981). Economists free ride: Does anyone else? Journal of Public Economics, 15, 295-310.

Mayer, R. R. (1970). Management's responsibility for purchasing ethics. Journal of Purchasing, 4, 1320.

Mayo, M. A. \& L. J. Marks. (1990). An empirical investigation of a general theory of marketing ethics. Journal of the Academy of Marketing Science, 18 (Spring), 163-72.

Menguc, B. (1997). Organizational consequences, marketing ethics, and salesforce supervision: Further empirical evidence. Journal of Business Ethics, 16, 1-20.

Morgan, R. E. \& S. D. Hunt. (2002). Determining marketing strategy: A cybernetic systems approach to scenario planning. European Journal of Marketing, 36 (4), 450-78.

North, D. C. (1990). Institutions, Institutional Change, and Economic Performance. Cambridge, UK: University of Cambridge.

Petty, R. E. \& J. T. Cacioppo. (1986). Communication and persuasion: Central and peripheral routes to persuasion. New York, NY: Springer-Verlag.

Phelps, E.S. (1975). Altruism, morality, and economic theory. New York, NY: Russell Sage Foundation.

Rest, J. R. (1986). Moral development: Advances in research and theory. New York, NY: Prager Publishers.

Shaub, M. K. (1989). An empirical examination of the determinants of auditors' ethical sensitivity. (Unpublished doctoral dissertation). Lubbock, TX: Texas Tech University. 
Singhapakdi, A. \& S. J. Vitell. (1990). Marketing ethics: Factors influencing perceptions of ethical problems and alternatives. Journal of Macromarketing, 10 (Spring), 4-18.

Singhapakdi, A. \& S. J. Vitell. (1991). Research note: Selected factors influencing marketers' deontological norms. Journal of the Academy of Marketing Science, 19 (Winter), 37-42.

Sparks, J. R. \& S. D. Hunt. (1998). Marketing researcher ethical sensitivity: Conceptualization, measurement, and exploratory investigation. Journal of Marketing, 62 (February), 92-109.

Teece, D. \& G. Pisano. (1994). The Dynamic Capabilities of Firms: An Introduction. Industrial and Corporate Change, 3 (3), 537-56.

Trevino, L. K. (1986). Ethical decision-making in organizations: A person-situation Interactionist Model. Academy of Management Review, 11 (3), 601-17.

Tubbs, M. E. \& S. E. Ekeberg. (1991). The role of intentions in work motivation: Implications for goalsetting theory and research. Academy of Management Review, 16 (1), 180-199.

Vitell, S. \& J. G.P. Paolillo. (2003). Consumer ethics: The role of religiosity. Journal of Business Ethics, 46 (2), 151-62.

Vitell, S. J., J. G. P. Paollilo, \& J. J. Singh. (2005). Religiosity and consumer ethics. Journal of Business Ethics, 57 (2), 175-181.

Vitell, S. \& S. D. Hunt. (1990). The general theory of marketing ethics: A partial test of the model. In J. N. Sheth (Ed.), Research in Marketing Vol. 10 (237265) Greenwich, CT: J.A.I. Press.

Volker, J. M. (1979). Moral reasoning and college experience. Unpublished manuscript, Minneapolis, MN: The University of Minnesota.

Williams, O. F. \& P. E. Murphy. (1990). The ethics of virtue: A moral theory for marketing. Journal of Macromarketing, 10 (Spring), 19-29.

Williamson, O. E. (1975). Markets and hierarchies: Analysis and anti-trust implications. New York, NY: The Free Press.

Williamson, O. E. (1979). Transaction-cost economics: The governance of contractual relations. Journal of Law and Economics, 22, 233-261.

Williamson, O. E. (1981). The modern corporation: Origins, evolution, attributes. Journal of Economic Literature, 19 (Dec.), 1537-1568.
Williamson, O. E. (1993). Opportunism and Its Critics. Managerial and Decision Economics, 14, 94107.

Williamson, O. E. (1994). Transaction cost economics and organization theory. In N.J. Smelser and Swedberg (Eds.), The Handbook of Economic Sociology 77-107. Princeton, NJ: Princeton University Press.

Zey-Ferrell, M., K. M. Weaver, \& O. C. Ferrell. (1979). Predicting unethical behavior among marketing practitioners. Human Relations, 32 (7), 557-569. 